\title{
GCU
}

Glasgow Caledonian

University

University for the Common Good

\section{Introduction to the politics of life: a biopolitical mess}

Bird, Greg; Lynch, Heather

Published in:

European Journal of Social Theory

DOI:

$10.1177 / 1368431019838455$

Publication date:

2019

Document Version

Author accepted manuscript

Link to publication in ResearchOnline

Citation for published version (Harvard):

Bird, G \& Lynch, H 2019, 'Introduction to the politics of life: a biopolitical mess', European Journal of Social Theory, vol. 22, no. 3, pp. 301-316. https://doi.org/10.1177/1368431019838455

\section{General rights}

Copyright and moral rights for the publications made accessible in the public portal are retained by the authors and/or other copyright owners and it is a condition of accessing publications that users recognise and abide by the legal requirements associated with these rights.

Take down policy

If you believe that this document breaches copyright please view our takedown policy at https://edshare.gcu.ac.uk/id/eprint/5179 for details of how to contact us. 


\title{
Introduction to the Politics of Life:
}

\section{A Biopolitical Mess ${ }^{\mathrm{i}}$}

\author{
Greg Bird
}

Wilfrid Laurier University

\section{Heather Lynch}

Glasgow Caledonian University

\section{Abstract}

This introduction to our special issue focuses on the messiness of biopolitics. The biopolitical is a composite mixture of heterogeneous, and sometimes conflicting, forces, discourses, institutions, laws, and practices that are embedded in and animated by material social relations. In the now extensive literature on biopolitics, our biopolitical era is characterized by the blending and mixing of what were previously thought of as separate realms: life is biologized, politics is biologized and biology is politicized, life and politics have been economized, and making life is intertwined with making death. This paper provides a general overview of two strains of these biopolitical entanglements. We begin by examining the largely French and Italian focus on how politics and life have become economized in contemporary neoliberalism. We then turn to the largely AngloAmerican focus on the biologization of life. We conclude by taking up the central problem that arises from the messiness of biopolitics: whither the political of the biopolitical economy of life? Is there such a thing as the political proper in our era? If not, then what type of politics must be deployed to address the issues of our biopolis?

\section{Key Words}

Anthropocene, Biopolitics, Foucault, Geontopolitics, Homo oeconomicus, Necropolitics, Posthuman

For the first time in history, no doubt, the biological [le biologique] was reflected in the political [le politique]; the fact of living was no longer an inaccessible substrate that only emerged from time to time... part of it passed into knowledge's field of control and power's sphere of 
intervention.... For millennia, man remained what he was for Aristotle: a living animal with the additional capacity for a political existence; modern man is an animal whose politics places his existence as a living being in question. (Foucault, 1976: 187-188; 1990: 142-143)

How many texts on biopolitics open with this seminal passage from the closing chapter of Michel Foucault's The Will to Knowledge? In another prolegomenon to biopolitics, Homo Sacer, Giorgio Agamben argues that 'society's "threshold of biological modernity" ii occurs when 'the species and the individual as a simple living body become what is at stake in a society's political strategies' (1998: 3). Put differently, what is at stake is the bio-politicization of life. There are two sides to this process. On the side of knowledge's field of control, life is subjected to the science of biology, life is biologized. On the side of power's sphere of intervention, politics are biologized and biology is politicized (Esposito, 2008: 147). The net result is that life is not just subjected to politics or biology per se, but to bio-politics. Life is the biopoliticized subject matter of biopower. This intertwinement of the political and the biological has created such a mess that it has become impossible to speak of either as if they stand on their own terms in their own proper spheres. In our biopolitical era, each is fodder for the other (see Malabou, 2016).

Biopolitical thought, however, is not just concerned with the entanglement of the biological and the political, because the biopolitical is a composite mixture of heterogeneous, and sometimes conflicting, forces, discourses, institutions, laws, and practices that are embedded in and animated by material relations. Between the last chapter of The Will to Knowledge and his concluding lecture on March 17, 1976 in the Society Must Be Defended lecture series (2003), Foucault established at least five specific vectors that have become core issues in the messiness of the biopolitical. The first two, already discussed, received great uptake in the first Anglo-American wave of biopolitical thought. First is the fact that life has become increasingly dominated, controlled, and subjugated by the biological sciences. Beyond the anthropocentric issues addressed directly through Foucault's insights such as epidemiology, natalist policies, demography, biotechnology, biopolitical thinkers have taken up the nature/cultural dialectic, the Anthropocene, animal rights, synthetic biology, and so forth (Wolfe, 2015; Tiessen, 2015; Povinelli, 2015). Second, the biologization of politics led to a perversion, even an undermining, of the political. Politics was governmentalized. The people (demos) becomes a biological population that must be managed, regulated, and controlled. In the field of governmentality, texts cover topics from state racism, eugenics, neoliberalism, healthism, social hygiene, security, to normalization, and so on (Rose, 2007; Dillon and Lobo-Guerrero, 2009; Braun, 2007). What is often forgotten in both these lines of inquiry is that Foucault never claimed that the bio-politicization of life has become a fait accompli, as if life has been completely appropriated and 'totally integrated into techniques that govern and administrate it,' because life also 'constantly escapes them' (Foucault, 1990: 143).

Three related issues that arise from the messiness of biopolitics have been emphasized in a different reception, possibly a second wave, of biopolitical theory. Each has been addressed through more philosophical and politicized terms than the first two. 
The third and fourth hail largely from the Italian and French inflections of biopolitical theory. The third concerns the relationship between life and death in biopolitics, of making or letting live and making or letting die. Foucault was relatively vague, even contradictory, about this relationship. In The Will to Knowledge he claims that biopower 'supplanted' sovereign power (1990: 140), but in Society Must Be Defended he argues that biopower 'complemented' and 'permeate[d]' sovereign power (2003: 241). Agamben's own prolegomenon to biopolitics attempts to revise the relationship between sovereign and biopower (1998). Roberto Esposito's Bios is dedicated to teasing out this problem of continuity and discontinuity in the biopolitical literature (2008). Either biopolitics represents a politics of life or over life. Esposito also addresses the relationship between life and death in his study of the modern immunization paradigm (2011).

The issue of the relationship between life and death is taken up in the complementary issue of the division or caesura 'within the biological continuum' of life (Foucault, 2003: 255). Foucault's hasty discussion of 'state racism', first introduced in details to the English readers by Anne Laura Stoler (1995), raises the issue of the asymmetrical distribution of life and the deployment of negative biopolitical measures against some lives in order to preserve and improve other lives. Agamben can be credited for advancing this strain when he circles back to Aristotle to develop his distinction between two forms of life: bios and $z o \bar{e}(1998)$. Life is subjected to a normative evaluation between higher and privileged forms of proper life and lower, degraded, and excluded forms of improper life (see Campbell, 2011). In an effort to 'correct' or 'complete' the 'Foucauldian thesis', Agamben argues that modern biopolitics arise in the deployment of the sovereign 'state of exception' which targets 'bare life' as the subject and object of politics (1998: 9). Biopolitics emerges, then, when zoè is politicized.

The third and fourth issues have given rise to more politicized and critical strains in biopolitical thought. Achille Mbembe's decolonial theory of necropolitics (2003), for example, has become a staple in this literature. This is partly because he adds a critical race dimension to this literature, but also because this theory does not end on the claim that there is a normative distinction between two classes of life (bios and $z o \bar{e}$ ), which we find in so many applications of Agamben's theory. With necropower, the normative distinction is intricately woven through relations of domination and control such that proper lives are directly or indirectly enhanced by subjugating improper lives. The death or creation of death-like or death-fostering conditions for some serves to enhance the lives of others. In other words, it is impossible to separate what Foucault called the 'death-function' (2003) from what feminist biopolitical theorist Jemima Repo calls the 'life-function' (2015). In the Israeli apartheid state, for example, the lives of Israeli citizens are directly enhanced by debilitating and maiming the lives of Palestinians (Puar, 2017), or by subjecting Palestinians to a 'death world' (Mbembe, 2003), or by destabilizing daily Palestinian life up to the point of suffering as Homo dolorosus (see Wells, 2019 in this issue). In a different colonial setting, Canada, the lives of white settlers have been enhanced by subjugating, exploiting, appropriating, and negating Indigenous bodies, cultures, lands, and traditions (Morgensen 2011; Mosby 2013). 
There is a fifth messy issue in biopolitics: political-economy. Again, this issue was present in Foucault's two précis on biopolitics, as well as his lectures on rise of neoliberalism aptly titled The Birth of Biopolitics (2008), but it has only been fully articulated with the writings of several second generation Italian and French biopolitical theorists. Once biologized life was politicized, politics become invested in managing, regulating, and controlling the sphere of where life was enabled -- the oikos or the home - the economy and politics became, in Foucault's terms, governmentalized. Countless texts have addresses issues on this account, ranging from the literature on reproductive/immaterial labour, the social worker, economic theology, governing by debt, up to bioprospecting. Neoliberal biopolitics are thoroughly economized. When pushed, this perspective opens up an even more intricate understanding of the division of life. Life is not just subjected to normative distinctions between valuable and invaluable life, and this distinction is not only based in relations of domination and control, because life is also expropriated and asymmetrically distributed in ways that directly enhance and enrich some lives while diminishing others. The valuation of life is materially embedded in relations of domination and exploitation; that is, in a biopolitical economy of life.

Proper lives are vitalized by exploiting and appropriating the life of improper lives, from surrogate mothers, sex slaves, organ theft and trade, up to migrant labourers, sweatshop labourers, and domestic workers. Life today is a capitalist resource.

Taken as a whole, these five pivotal biopolitical entanglements - the biologization of life, the biologization of politics, the relationship between life and death, the division and valuation of life, and the economization of politics and life - have created a wonderful mess of our world. This introductory essay will focus on two of these messy issues. We begin by examining the economization of politics and life. In the second section, we will focus on the biologization of life. These two issues are the primary focal points of the articles in this special issue. We shall conclude by taking up the central problem that arises from the messiness of biopolitics: whither the political of the biopolitical economy of life? Is there such a thing as the political proper in our era? If not, then what type of politics must be deployed to address the issues of our biopolis?

\section{The Biopolitical Economy}

In addition to the conflation of the biological with the political, one of the most pressing messes in our contemporary neoliberal biopolitical era is their convergence with the economic. Biopower, Foucault notes, was 'an indispensable element in the development of capitalism', which required 'the controlled insertion of bodies into the machinery of production' (disciplinary mechanisms) and 'the adjustment of the phenomena of population to economic processes' (regulatory mechanisms) (1978: 140-1). In our neoliberal era, it no longer makes sense just to speak of biopolitics, but also of a biopolitical economy. The biopolitical economy has been ushered in by a heterogenous assemblage of relations of force and knowledge consisting of discursive frameworks that establish the parameters and conditions through which we see, think and act in the world, institutions that establish laws, policies, and regulations, and material relations and practices that produce, reproduce, and expand its scope. Life today is discursively, institutionally, and materially entangled and embedded within this biopolitical economy. 
In the biopolitical literature, several paths have been identified as contributing to the rise of the biopolitical economy. On a material level, most forms of biological life, some might even say all forms of life including life itself, have been economized. Everything from the microbiological (DNA, stem cells, genetically modified organisms) to the macrobiological (farmed animals, domestic pets, insects, plants, even human slaves), from outer atmosphere to inner core, from sea to land, has been converted into economic matter. Feminist and decolonial science and technology studies scholars have examined the impacts of commodifying everything from pets (Haraway, 2008) to indigenous DNA (TallBear, 2013). Early biopolitical texts pointed to the process whereby life become biocapital. Not only was life being subjected to 'biopiracy' (Shiva, 1997) and rendered a 'bio-value' (Rose, 2007a), colonized and commodified, but life was also being 'made to work for production and production [was being] made to work for life' (Hardt and Negri, 2000: 32). Neoliberal globalization from above has accelerated this process. Life has been thoroughly economized across a number of scales, from international financial institutions and trade agreements, bio-prospectors working for transnational corporations, the recognition of patent laws by national governments, policies enacted by global non-governmental organizations, to local campaigns waged against the privatization and commodification of biological life.

The economization of life has not just been implemented in a top-down, direct manner because there are many more paths that have been analyzed to explain the rise of the biopolitical economy. We shall just cover two here: the rise of Homo oeconomicus and the politicization of the oikos. The first is outlined in detail by Foucault in his lecture series on the birth of biopolitics (2008). This somewhat bewildering lecture series that purports to examine the birth of biopolitics yet makes but fleeting direct references to biopolitics nonetheless provides a framework for understanding the conflation of the biological, political, and economic. At issue in these lectures is the transformation of the 'governmental regime of liberalism' from the classical to the neoliberal model. Foucault argues that the liberal principle of limited government is animated by the tension between the economic and the political. In classical liberalism, this tension arose in the conflict between two competing models of the subject: Homo oeconomicus versus Homo juridicus. The 'subject of interest' was concerned with the marketplace and exchange whereas the 'subject of right' was concerned with laws and positive rights. These two subjects were incompatible, with the economic subject producing individualizing effects and the political-legal subject producing totalizing effects (2008: 282). The social contract served as a compromise to ease these countervailing forces of interests and rights.

With the rise of neoliberalism, however, Homo oeconomicus is recalibrated and invigorated. In lieu of exchange and interests, this entrepreneurial subject is concerned with competition, production, and enterprise (2008: 147). The social contract is no longer able to contain this subject and keep it in line with the demands of the juridical subject so neoliberal governmentality turns to a new terrain of 'civil society' to address the incompatibility of the economic and juridical subjects. Civil society also becomes the core target for the neoliberal reaction against Keynesian policies in the U.S. It is at this very point of tension where the birth of the biopolitical economy starts to make sense. From this entry point, one merely has to circle back to a number of issues he 
raised in his two previous lecture series on biopolitics, including the defense of society, governmentality, the dispositif of security, the dispositif of policing, state racism, demography, and population $(2003 ; 2007)$. Civil society, society, the social, or the nation becomes the terrain and target of biopolitical governance.

Foucault's relatively early and cursory account of the rise of neoliberal governmentality has been taken in several directions. Wendy Brown (2015), for example, argues that Foucault could not have foreseen how extensively economized Homo oeconomicus would become. Under the logic of human capital, collective and individual, neoliberal individuals are made to govern themselves. Foucault's focus on Homo juridicus, Brown argues, also led him to ignore how neoliberal governance was fundamentally undermining democracy and what she calls 'homo politicus'. Others have focused on the role of debt in neoliberal governance. Besides Gilles Deleuze's (1992) brief mention of debt in his essay on the society of control, others examine how indebted subjects, from national governments to private individuals, are targeted by governmentalizing apparatuses (see Lazzarato 2012, 2015; Stimilli 2017, 2018). No longer are political apparatuses necessary to manage, regulate, and control an indebted population. In fact, with the neoliberal attack on society, the social is no longer deployable as a device to mediate between the conflicting demands of the subject of interests and the subject of rights. Instead, Maurizio Lazzarato (2012: 122-128) argues, Homo debitor takes its place. Subjects are pacified by the burden of debt. Not only are they institutionally and materially incapacitated by debt, they also personally internalize debt as guilt, which is reinforced every time they are reprimanded by a bank, creditor, or other agents of finance. The labour market further punishes them by offering them precarious employment. Their docility, even hegemonic pathos, is only further exasperated when they internalize the governing logic of human capital and their struggles are articulated on personal terms, as if their personal worth has been miscalculated. Indebted subjects have been so extensively economized that it is hard to find a politics emanating from their collective causes when they take them up using the same meritocratic logic. The labour movement has long had a name for this: "business unionism."

Neoliberal governance, in short, thoroughly economizes politics and thus renders politics impolitical. This process extends well beyond economic goods and services as it penetrates into the heart of the discursive framework of politics itself. After centuries of colonization, twentieth century totalitarianism, neoliberal globalization, and now the rise of ultra-right populism, one does wonder if the very conditions that were thought to enable democracy are still present today. One does have to ask, however, if the rule of the people was undermined once the people became a population that was to be studied, recorded, and described demographically and subsequently managed, manipulated, and regulated by specific policies (see Foucault 1990, 2003). It is no surprise that this same population, which was first converted into various demographics and then thoroughly economized, has become attracted to populism. In our new era of popularchy, the two primary political issues are the population and the economy. Popularchs are elected on the grounds of being the most capable of protecting a particular demographic of the population and the most efficient at managing the economy. Donald 
Trump is the quintessential popularch. Esposito (2019) addresses some of these issues in his contribution to this special edition 'Postdemocracy and Biopolitics'.

A second related pathway that accounts for the contemporary confluence of the biological, economic, and political is found in the writings of Agamben, Esposito, and many feminist writers. When life became a central target of politics, politics also became wrapped up with the oikos. The oikos is the home, the sphere of reproduction where the basic needs for the species are met and managed. Not only does the public become invested in the private sphere (Arendt, 1998), but also with managing life and life processes (Agamben, 1998). If the economy becomes politicized and politics economized, then we are left with a near state of exception, or what Agamben (2015) refers to in reference to ancient Greece as a period of civil war or stasis which is necessary to reestablish the equilibrium between politics and economics. Agamben (2011) and Esposito (2015) have also pointed out that a second source of this conflation lies in the economic-managerial paradigm of Christian providence in the Trinitarian oikonomia. In this special issue, Elettra Stimilli argues that one of the key mechanisms supporting neoliberalism is the 'faith' in the marketplace (2019). A sort of economictheological paradigm animates neoliberal governance in lieu of the former politicaltheological paradigm. And, as Hannah Richter asks in this special issue, does Agamben's 'form-of-life' (2016) have the political capacity to resist neoliberalized biopower (2019)?

The politicization of the household and home economics brings us full circle back to a series of issues, including the patriarchal division of labour, reproductive labour, immaterial labour, even racialized labour. All of these are represented today in a new form of labour that has emerged in our biopolitical economy that could be called 'biological labour'. 'iii Biological labour is both productive and reproductive labour that is repetitive and nonenduring but nonetheless necessary for the biological sustenance and reproduction of our species. Biological labourers are also biological precisely because their lives are devalued to such an extent that they are reduced to mere biological existence. In human form, biological labourers are also reduced to their mere biological existence through essentializing discourses of race and/or sex. Politically they are treated as a lower form of life that is denied full, or at times even partial, access to the polis (i.e. $z o \bar{e})$. Economically, their labour is either undervalued and poorly compensated, such as the reproductive and/or agricultural labour conducted by migrant labourers in the Global North or the reproductive labour conducted by surrogate mothers in the Global South. Other non-human biological labourers, it must be noted, are not economically compensated at all, such as dairy cows who produce milk, maple trees that produce maple syrup, or honey bees that produce honey.

Biological labour, whether human or non-human, is subjected to economic evaluation, appropriated, and exploited. Even though it is undervalued, biological labour still holds some economic value because it is commodified and it must be sustained in order to remain productive. As an undervalued form of labour, however, the package of biopolitical rights and programs that are deployed to enhance privileged forms of life (bios) which could be called 'vital life', are not extended to them, such as workplace safety regulations, minimum wages, health care, social insurance, education, etc. When employed in the Global North, biological labourers are actively denied the biopolitical 
package of life enhancing rights and programs. There is definitely a necropolitical dimension to this relationship, but the necropolitical paradigm focuses too much on political domination and subordination. When factoring in the economic dynamics, there is much more happening than merely maiming (Puar, 2017) or subjecting biological labourers to death worlds (Mbembe, 2003), even a 'slow death' (Berlant, 2007), because the life of biological labour still holds some value that is appropriated and exploited. Biological labour is a form of life that has been thoroughly biologized, economized, and thus depoliticized. It is, in short, a perfect neoliberal version of biopolitical subjectivity. In our era, biological labour has become one of the key figures in social and economic justice struggles. Biological labour is also a key site for re-politicizing our biopolitical economy.

Of course, in our cursory exploration of biological labour we have conflated a number of issues and we have flattened out a number of structural forms of discrimination. There remains a hierarchical order even within the category of biological labour. But it is not our intention to establish a scale here, for there are many existing that could be used to sort through how different lives are over-valued and under-valued in our biopolitical economy. Rather, we want to emphasize the significance of biological labour as a new form of subjectivity in the neoliberal biopolitical economy that divides, values, appropriates, exploits, and asymmetrically distributes life. It is here that the collapse of the political, economic, and biological is most evinced in neoliberal forms of human, as well as non-human, labour.

\section{Biopoliticization of Life Revised}

Foucault's anthropocentric account of biopower has been subjected to much criticism in contemporary biopolitical theory, especially in the dominant fields in the AngloAmerican sphere, such as science and technology studies, environmental philosophy, and posthumanism. Posthumanist theorists, for example, have noted that he provides a 'cartography for a world that no longer exists' (Braidotti, 2015: 37) or one that remains within the 'traditional humanist orbit' (Barad, 2007: 235). Thomas Lemke (2014) questions Foucault's focus on just subjugated human bodies and regulated human populations. In the following section, we provide an overview of two dimensions of this critique. We start with the molecular account of how human life is itself entangled in a web of life by focusing on the two main trajectories of this approach, biogenetic science and Infection Prevention Control (herein IPC). We finish by examining the global account of how life expands beyond the human by taking up the debate about the Anthropocene. From the molecular to the global, scholars in these fields have been systematically trying to destabilize, weaken, and exhaust the human's control over biopower. What if the biopolis is no longer that biopolitical arena where life is subjected to biocratic politics, always human 'power over life', but a sphere where, to push Esposito's dichotomy further, the 'power of life' can be realized (2008)?

The politics of molecular life has two main trajectories biogenetic science and Infection Prevention Control (IPC). The first engenders the engineering up to the 'creation' of life. The second attempts to manage human-bacterial relationships. Biogenetics is based on a future where humanity has the capacity to shape the bodies they inhabit and eradicate DNA 'flaws' that are viewed as limiting the quality of life. In the 
Anglo-American reception of Foucault's biopolitical theory, Nicholas Rose (2007a, 2012, 2013) has written extensively on the biopolitics of 'life itself.' Rose argues biotechnology has dramatically altered the focus of governance from the management of risk in populations to the management of genetic risk within individuals. He envisions a future where individuals carry their personal codes in their pockets on a $\mathrm{CD}$. He claims that biopolitics today have become 'ethopolitics' because bioscience targets individuals and renders them responsible for how they live (i.e. their ethos), and for their genetic contribution (Rose, 2007b). He advances this claim through a misreading of Foucault's notion of biopower. Biopower, Rose claims, only operates on a collective level on populations (2007a: 27), which ignores biopower's second vector that subjugates bodies (Foucault, 1990: 14), and Foucault's writings on governmentality (2007) and the birth of biopolitics (2008). Rose draws from Rapp's (1999) study of amniocentesis, a test on the embryo for abnormalities, as evidence of this shift towards a new form of identifying risky bodies and new apparatus to manage them. This 'would not merely seek the avoidance of sickness or premature death', Rose (2017b: 17) claims, 'but would encode an optimization of one's corporeality to embrace a kind of overall 'well-being' - beauty, success, happiness, sexuality and much more'. When life becomes code, there are new possibilities for human mastery, such as Chinese scientist He Jiankui's recent claim to bioengineering the twins Nana and Lulu (Seidel, 2018). The ethopolitics arising from biotechnological advances do not just concern unintended risks, they also entail a normative and ableist judgement against so-called 'flawed' differently abled life which becomes treated as disposable life (Hughes, 2000). However useful Rose's ethopolitics might be in such contexts, it has been criticized for remaining trapped within the boundaries of the individual human body (Braun, 2007, Povinelli, 2016).

The other primary approach to molecular life, on the contrary, examines how molecular life traverses bodies and geographies. IPC focuses on the micro-arena of bacterial invasion (in-fectus) of human and animal bodies. From a multiscalar perspective, IPC follows the movement of bacteria across national borders and the boundaries of human bodies (Memesh et al, 2007). From the intimacy of a private bathroom to the boardroom of WHO, IPC opens up a vision of the human/more-thanhuman entanglements of life. The notion that humanity must govern bacterial life first emerged with the social hygiene movement and the creation of Penicillin. Biopolitical apparatuses now took their aim at microbiological life by deploying antibiotics, pesticides, herbicides and anti-bacterial cleaners. Rachel Carson (1962) raised awareness about the damaging impacts of attempting to govern life by deploying toxins with her popular book Silent Spring, but sadly it has taken several centuries for us to recognize the serious impacts that governing through toxic chemicals has had on our environment. Some scientists are even forecasting an 'antibiotic apocalypse' because of the antimicrobial resistance that is starting to form against the drugs we currently use to control bacteria in our bodies. ${ }^{\text {iv }}$ Drawing on Esposito's theory of immunization, Nik Brown (2019) reads IPC as an attempt to guard the borders between human and non-human life. This 'biotic politics', Brown (2019) argues, creates a pharmaceutical market to promote the good and destroy the bad. This division, of course, is not so clear and it results in a relentless production of new biotic toxins and the rise of highly resistant 'superbugs'. Our contemporary pharmaceutical economy is driven by its self-produced crisis of antimicrobial resistance. 
Bruce Braun (2013) argues the relentless engine of exclusion is acting 'against' rather than 'with' life. In contrast Esposito's affirmative biopolitics, calls for a 'nonexcluding relation with the common opposite' (Esposito, 2011: 17). Life lives across bodies; thus, we must develop new strategies that challenge the logic of AMR. In this special issue, Heather Lynch's paper ‘Esposito’s Affirmative Biopolitics in Multispecies Homes' explores how recognition of shared vulnerability allowed research participants to work through abjection and achieve peace with the insects with whom they shared their home. This involved viewing the home as 'borderland' rather than fortress and developing the 'immunocompetence' required to live in a more-than-human, multispecies home (Lynch, 2019). To work 'with life' would involve reinterpreting and redeploying science. The scientific developments which have emerged from the Human Genome Project $^{\mathrm{v}}$ and the Human Microbiome Project ${ }^{\mathrm{vi}}$ make it very clear that human life was never discrete and separate from all cellular life. That an average human relies on more non-human microbiota than human cells, argues Penelope Ironstone (2019) in this special issue, and that the human genome has the same level of complexity as a fruit-fly, at least in one register, challenges the longstanding tradition of human exceptionalism and forces us to examine the microbiological interconnectedness of all life. Posthuman scholarship, for example, seeks a political shift away from the Cartesian anthropocentricism which underpins the liberal order (Wolfe, 2010; Braidotti, 2013; Povinelli, 2016). The power of life does not belong to humans but is distributed across all life (Despret, 2013).

The second set of challenges to human control over biopower take a more global perspective. Today the topic that is gaining the most traction is the debate concerning the 'Anthropocene'vii. Earth scientists Crutzen and Stoermer (2000) first proposed this term as a new geological era in which human activity has generating a significant imprint on the geology and ecosystems of the planet. It is a complicated discourse filled with contradictory positions. Many proponents extol the potential of technological progress, yet they also admonish the potentially catastrophic impacts of human development. What is at issue in this strategic discourse is a 'vector of control' (Tiessen, 2018). In the remainder of this section we examine two dimensions of control: the technological and economic.

In the Anthropocene debate, technology is a central issue. For many, this era begins with the advent of industrialisation (Malm, 2016; Angus, 2016). The extraction and burning of fossil fuels, for example, has fostered incredible human advances in technology and development, but it has come at a cost of environmental degradation, species-extinction, and global warming that is especially felt in the Global South. Since human technology has ushered in the Anthropocene, then human technology can be deployed to solve our current crisis. Technology can be managed. We can strictly limit the use of fossil fuel dependent technologies while developing new technologies that are powered by green energy sources, such as wave, wind, and solar power. This celebratory discourse of human biopower over life, also turns its attention to managing other species, such as the strategy of 'rewilding' to create 'nature'-based solutions. Risk must be managed by redistributing energy and species. Notwithstanding debates concerning the merits of particular strategies, there is consensus that, despite the scientific possibility of addressing the core issues posed by the Anthropocene, issues remain when considering the social, economic, and political impacts of implementing them. 
Those who focus on the social and economic dimension of control over life draw attention to the political economy of energy production and use (Sklair, 2017). Ian Angus (2016) and Andreas Malm (2016), for example, ask who has benefited from the burning of fossil fuels. Jason Moore (2015) argues that, instead of the Anthropocene, we should use the term 'Capitalocene' because it focuses on the economic origin of this geological shift. Beyond the hyper-acceleration of economic growth that defines this period, there is a question of exploitation and inequality. Although much of this growth can be attributed to the Global North, states in the Global South disproportionately bear the brunt of the negative impacts (Costello et al, 2009). Climate change is yet another latent effect of neocolonialism in the Global South.

In the Global North today we are witnessing the rise of neoliberal popularchy. A number of populations that have become used to modes of living that are carbon dependent are turning away from their traditional parties and electing popularchs who promise to sustain, even enhance, their carbon consuming lifestyles and industries. Through protectionist and economic nationalist policies, they are undermining international agreements that aim to reduce carbon emissions. As we discussed in the previous section, this mess can be partially attributed to the neoliberal conflation of the political, economic, and biological. Popularchs are elected to protect particular demographics, including their lifestyles, and to protect the national economy from external regulations. Given the rise of climate denying popularchs, the ineffectiveness of capitalist governing apparatuses, from regional, state, up to international political institutions, and the ontological crisis we are facing, the question must be asked: Are our current 'democratic' institutions and practices capable of addressing this problem?

What is evident in each of these accounts on the current 'power over life' paradigm is that while we have generated new technological freedoms, each has also produced unintended consequences, culminating in the ultimate crisis of existence, even life, itself. A self-produced crisis resulting from human life exercising its power over life. It is as if the thanatopolitical dimension has directed modern biopower over life to turn in on itself, in a sort of suicidal drive. The greater the power over life, the greater the need for protection from the known and unknown harms this may create. In other words, attempts to divide life into what is governable and indeed to draw more life into the category of the governable creates more resistance. Power over life is constitutive of the contemporary condition of precarity, a precarity produced through the realisation that there is no distinction between bíos and $z o \bar{e}$, that being in and against itself is constitutive of unfolding life. Esposito (2008: 88) states that 'identifying life with its own overcoming means that it is no longer 'in-itself' - it is always projected beyond itself.' A politics that does not seek to eradicate this resistance but lives with it may therefore provide the most sustainable and least destructive way forward.

Prevalent responses to this crisis include denial or more technology. More critical responses question whether a crisis produced by human power over life can be solved by applying more human power and instead call for a reconfiguration of what the human is within a more than human ecology of life. Elisabeth Povinelli (2016), for example, argues that we need to understand the operations of geontopower, which is a power which does not distinguish between life and nonlife. She claims that Foucault's 'figures of biopower 
(the hysterical woman, the Malthusian couple, the perverse adult, and the masturbating child; the camps and barracks, the panoptican and solitary confinement)' have given way to 'new figures, the Desert, the Animist, the Virus' (2016: 119). These figures attend to a distribution of life beyond bíos and $z o \bar{e}$, and the individual who carries life in a CD. Human life is enfolded in more than human life in which human life is both enabled and in conflict. In this special issue, Federico Luisetti (2019) addresses the strengths of the geopower thesis, a play on Povinelli's geontopower, especially given that the subject that must be addressed today is the neoliberal Homo oeconomicus. Donna Haraway (2016) rejects the term Anthropocene as continuing the man-centric narrative while relying on an 'unthinkable theory of relations, namely the old one of bounded utilitarian individualism' (Haraway, 2016). She proposes the 'Chthuluscene', which conveys the connectedness of life. She muses that 'myriad tentacles will be needed', tentacles which reach across spacetime, a rejection of a humanist anthropocentric view, a call toward something else, something not yet imagined. She calls for 'a thousand somethings else, still telling of linked ongoing generative and destructive worlding and reworlding'. The Chthuluscene is an image of a mode of understanding which recognises that there always destruction and life that lives needs to 'stay with the trouble'. That we have to attend to the biopolitical messiness of our world, in other words, does not mean that we must dominate it or purify it.

\section{Conclusion}

The political today is nothing more than an empty shell, penetrated and invaded by so many interceding forces and discourses such that it is no longer feasible to appeal to it alone and its terms when searching for political guidance. The question we must ask today is what can be done with this mess? Should we attempt to sort out, separate, and clean out the various parts, as if they can be placed back into their own proper places, own spheres? If bios dominates the bio-polis, does that mean that all degraded forms of life from human to non-human $z o \bar{e}$ should strive to be properly included? Moreover, what can be done with a biopolitical order that has been so thoroughly economized that its politics are de-politicized, even impoliticized? How is it possible to de-economize biopolitics when life is reproduced and natured in the oikos?

To look after and care for our, and every living thing's, house does not mean that it must be sorted, purified, and cleaned. Puritan solutions will only further intensify the thanatopolitical divineness that has come to define our biopolitical order. Our former categorical distinctions - such as nature/culture, human/non-human, politics/economics, bios/zōe - no longer hold fast. The biopolitical mixture and confusion has rendered these categories obsolete. But not all is lost because the mixing of lives and confusion of categories presents new opportunities today. The matter of biopolitics is precisely our relatedness, our intermixing, and our co-dependency. If life is the materiality of our relationships, then life must be the matter of our politics. What matters, all that matters, is finding a way to attend to and affirm life. Biopoliticized politics must focus on attending to the mess, not dominating it, not purifying it. This recalibration is of the most urgent task of our time, which is now marked and limited by the ultimate crisis of life. These politics must be grounded in an ethics of sharing across the plurality of lives, each present in their singularity. This is not a passive, apolitical call to stand back and let the mess be. Such is not possible since the mess is in our own house. It must be attended to and we 
have to learn how to share in and through it. In our home we must comingle, eat, and thrive alongside others, including multiple species, sometimes eating each other. Our home is a multispecies mess hall. We can no longer think of this home as a single dwelling place, divided off and in opposition to others, as if it were a fortress that protects and shelters us from possible intruders. We must learn how to, in words we've already cited, 'stay with the trouble' (Haraway 2016). It is precisely the trouble that arises when engaging with the biopolitical mess that each of the papers in this special issue attends to.

\section{References}

Agamben G (1998) Homo Sacer: Sovereign Power and Bare Life. Translated by D Heller-Roazen. Stanford, California: Stanford University Press.

Agamben G (2011) The Kingdom and the Glory: For a Theological Genealogy of Economy. Translated by Lorenzo Chiesa. Stanford, California: Stanford University Press.

Agamben G (2015) Stasis: Civil War as a Political Paradigm. Translated by Nicholas Heron. Padstow: Edinburgh University Press.

Agamben G (2016) The Use of Bodies. Stanford: Stanford University Press.

Angus I (2016) Facing the Anthropocene: Fossil Capitalism and the Crisis of the Earth System. New York: Monthly Review Press.

Arendt H (1998) The Human Condition. Chicago: University of Chicago Press.

Bird G (2018) The Biopolitical economy of guest worker programs. In: Richter H (ed) Biopolitical Governance: Race, Gender and Economy. London: Roman \& Littlefield, pp. 99-120.

Barad K (2007) Meeting the Universe Halfway: Quantum Physics and the Entanglement of Matter and Meaning. Durham/London: Duke University Press.

Berlant L (2007) Slow death (sovereignty, obesity, lateral agency). Critical Inquiry 33(4): 754-780. 
Braidotti R (2013) The Posthuman. Cambridge: Polity Press.

Braidotti R (2016) Posthuman Affirmative Politics. In: Wilmer SE and Žukauskaite A (eds) Resisting Biopolitics: Philosophical, Political, and Performative Strategies. New York: Routledge, pp. 30-56.

Braun, B (2007). Cultural geographies biopolitics and the molecularization of life. Cultural Geographies, 6-28.

Braun B P (2014). A new urban dispositif? governing life in an age of climate change. Environment and Planning D: Society and Space, 32(1), 49-64.

Brown W (2015) Undoing the Demos: Neoliberalism's Stealth Revolution. London: Zone Books.

Brown N (2019) Immunitary Life: A Biopolitics of Immunity. London: Palgrave Macmillan

Campbell TC (2011) Improper Life: Technology and Biopolitics from Heidegger to Agamben. Minneapolis: University of Minnesota Press.

Carson R (1962) Silent Spring. Cambridge, Massachusetts: Riverside Press.

Costello A, Abbas M, Allen A, Ball S, Bell S, Bellamy R, Friel S, Groce N, Johnson A, Kett M, Lee M, Levy C, Maslin M, McCoy D, McGuire B, Montgomery H, Napier D, Pagel C, Patel J, Puppim de Oliveira J, Redclift N, Rees H, Rogger D, Scott J, Stephenson J, Twigg J, Wolff J, Patterson C (2009). Managing the health effects of climate change. Lancet and University College London Institute for Global Health Commission. The Lancet, 373(9676), 1693-1733.

Crutzen PJ and Stoermer EF (2000) The 'Anthropocene'. Global Change Newsletter 41: $17-18$. 
Delanty G and Mota A (2017). Governing the Anthropocene: Agency, governance, knowledge. European Journal of Social Theory, 20(1), 9-38.

Despret V (2013). From secret agents to interagency, History and Theory 52(52), 29-44.

Deleuze G (1992). Postscript on societies of control, October 59(4): 3-7.

Dillon M \& Lobo-Guerrero L (2009) The biopolitical imaginary of species-being. Theory, Culture \& Society, 26(1), 1-23.

Esposito R (2008) Bíos: Biopolitics and Philosophy. Translated by T Campbell. Minneapolis: University of Minnesota Press.

Esposito R (2011) Immunitas: The Protection and Negation of Life. Translated Zakiya Hanafi. Cambridge: Polity.

Esposito R (2015) Two: The Machine of Political Theology and the Place of Thought. Translated Zakiya Hanafi. New York: Fordham University Press.

Esposito R (2019) Biopolitics and democracy. Translated by G Bird. European Journal of Social Theory 3(22): pages tbd

Foucault M (1990) The History of Sexuality, Volume I. Translated by R Hurley. London: Random House. / (1976) Histoire de la sexualité I. La volonté de savoir. Paris: Gallimard.

Foucault M (2003) 'Society Must Be Defended': Lectures at the Collège de France, 1975-1976. Translated by D Macey. New York: Picador, Palgrave MacMillan.

Foucault M (2007) Security, Territory, Population: Lectures at the Collège de France, 1977-1978. Translated by G Burchell. New York: Picador, Palgrave MacMillan.

Foucault M (2008) The Birth of Biopolitics: Lectures at the Collège de France, 19781979. Translated by G Burchell. New York: Picador, Palgrave MacMillan. 
Hamilton S (2018) The measure of all things? The Anthropocene as a global biopolitics of carbon. European Journal of International Relations. 24(1) 33-57.

Haraway DJ (2008) When Species Meet. Minneapolis: University of Minnesota Press.

Haraway DJ (2016) Tentacular thinking: Anthropocene, Capitalocene, Chthulucene. EFlux, (75), 1-17.

Hardt M and A Negri (2000) Empire: The New World Order. London, England: Harvard University Press.

Hughes B (2000) Medicine and the aesthetic invalidation of disabled people. Disability and Society, 15(4), 555-568.

Ironstone P (2019). Me, myself, and the multitude: Microbiopolitics of the human microbiome. European Journal of Social Theory 3(22): pages tbd

Lazzarato M (2012) The Making of the Indebted Man: An Essay on the Neoliberal Condition. Translated by JD Jordan. Los Angeles: Semiotext(e).

Lazzarato M (2015) Governing by Debt. Translated by JD Jordan. Los Angeles: Semiotext(e).

Luisetti F (2019) Geopower: on the states of nature of late capitalism. European Journal of Social Theory 3(22): pages tbd

Lemke T (2016) Rethinking biopolitics: The New Materialism and the political economy of life. In: Wilmer SE and Žukauskaite A (eds) Resisting Biopolitics: Philosophical, Political, and Performative Strategies. New York: Routledge, pp. 57-73.

Lynch H (2019) Esposito's affirmative biopolitics in multispecies homes. European Journal of Social Theory 3(22): pages tbd

Malabou C (2016) One life only: biological resistance, political resistance. Translated by C Shread. Critical Inquiry 42: 429-438. 
Malm, A (2016) Fossil Capital: The Rise of Steam Power and the Roots of Global Warming. London, Verso.

Mbembé A (2003) Necropolitics. Public Culture 15(1): 11-40.

Memish ZA, Soule BM, and Cunningham G (2007) Infection control certification: A global priority. American Journal of Infection Control, 35(3), 141-143.

Moore JW (2015) Capitalism in the Web of Life. London, Verso.

Morgensen SL (2011) The biopolitics of settler colonialism: right here, right now. Settler Colonial Studies 1(1): 52-76.

Mosby I (2013) Administering colonial science: nutrition research and human biomedical experimentation in aboriginal communities and residential schools, 1942-1952. Histoire sociale/Social History 46(91): 145-172.

Puar, JK (2017) The Right to Maim: Debility, Capacity, Disability. Durham, North Carolina: Duke University Press.

Povinelli E (2016) Geontologies: A Requiem to Late Liberalism. Durham, North Carolina: Duke University Press.

Rapp Rayna (1999) Testing Women, Testing the Fetus: The Social Impact of Amniocentesis in America. New York: Routledge.

Repo J (2015) The Biopolitics of Gender. New York: Oxford University Press.

Richter H (2019) The eroticisation of biopower: masochistic relationality and resistance in Deleuze and Agamben. European Journal of Social Theory 3(22): pages tbd

Rose N (2007a) The politics of life itself: reframing political thought, Theory, Culture \& Society 18(6), 1-30. 
Rose N (2007b) The Politics of Life Itself: Biomedicine, Power, and Subjectivity in the Twenty-First Century. Princeton: Princeton University Press.

Rose N (2012). Democracy in the contemporary life sciences. BioSocieties, 7(4), 459472.

Rose N (2013). The human sciences in a biological age. Theory, Culture \& Society, 30(1), 3-34.

Seidel G (2018) How a scientist says he made a gene-edited baby - and what health worries may ensue, November 29, 2018 11.38am GMT

https://theconversation.com/how-a-scientist-says-he-made-a-gene-edited-baby-and-whathealth-worries-may-ensue-107764

Shiva V (1997) Biopiracy: The Plunder of Nature and Knowledge. Boston: South End Press.

Sklair L (2017). Sleepwalking through the Anthropocene. The British Journal of Sociology, 68(4).

Stoler AL (1995) Race and the Education of Desire: Foucault's History of Sexuality and the Colonial Order of Things. London: Duke University Press.

Stimilli E (2017) The Debt of the Living: Ascesis and Capitalism. Translated by Arianna Bove. Albany, New York: State University Press of New York.

Stimilli E (2018) Debt and Guilt: A Political Philosophy. Translated by S Porcelli. London: Bloomsbury Academic.

Stimilli E (2019) Religion and the spontaneous order of the market: law, freedom, and power over lives. European Journal of Social Theory 3(22): pages tbd

TallBear K (2013) Native American DNA: Tribal Belonging and the False Promise of Genetic Science. Minneapolis: University of Minnesota Press. 
Tiessen M (2018) Our Anthropocene: geologies, biologies, economies, and new pursuits of profit and power. Space and Culture, 21(1): pp, 72-85.

\section{Wells C (2019) Homo dolorosus: biopower and the politics of suffering. European Journal of Social Theory 3(22): pages tbd}

Wolfe C (2010) What Is Posthumanism? Minneapolis: University of Minnesota Press.

\footnotetext{
${ }^{\mathrm{i}}$ This special issue is the product of a two-day seminar held in Waterloo, Canada called 'The Politics of Life' (March 2-3, 2017) hosted by Technē: Wilfrid Laurier University Biopolitical Research Group and the Italian Thought Network. We must thank the Social Science and Humanities Research Council of Canada and the many offices at Wilfrid Laurier University who provided funding this event. Thank you also to Penelope Ironstone for your insightful comments. Finally, a special thank you to Gerard Delanty, all of the reviewers, and everyone else on the editorial team on the European Journal of Social Theory.

ii This phrase appears in the sentence preceding the sentence about Aristotle in The Will to Knowledge. Unfortunately, the English translation renders " "seuil de modernité biologique » d'une société' as 'society's "threshold of modernity", so we, once again, miss Foucault's emphasis on biology in this passage. In the epigraph, for example, 'le biologique' has been translated as 'biological existence' and 'le politique' as 'political existence'.

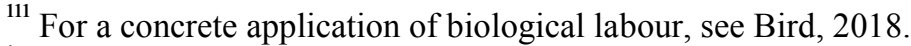

${ }^{\text {iv }}$ See statement by Dr. Margaret Chen, UN Health Summit, NY, 2016

${ }^{\mathrm{v}} \mathrm{https} / / /$ www.genome.gov/12011239/a-brief-history-of-the-human-genome-project/

${ }^{\mathrm{vi}} \mathrm{https} / / / \mathrm{hmpdacc}$. org/

vii The European Journal of Social Theory published a special edition on the subject of the Anthropocene and governance Delanty and Mota (2017)
} 